\title{
Growth, Yield and Economics of Transplanted Rice (Oryza sativa L.) as Influenced by Different Weed Management Practices
}

\author{
Jaladhar Gorain ${ }^{*}$, Koushik Patra ${ }^{2}$ and Parthendu Poddar ${ }^{2}$ \\ ${ }^{1}$ Department of Agronomy, Bidhan Chandra Krishi Viswavidyalaya, Mohanpur, \\ Nadia, West Bengal-741252, India \\ ${ }^{2}$ Department of Agronomy, Uttar Banga Krishi Viswavidyalaya, Pundibari, Cooch Behar, \\ West Bengal-736165, India \\ *Corresponding author
}

\section{Keywords}

Transplanted rice, Herbicides, Paddy weeder (PW), Weed control efficiency (WCE), Weed Control Index (WCI), Weed Index (WI) and yield components

Article Info

Accepted:

02 May 2018

Available Online:

10 June 2018

\section{A B S T R A C T}

Among the food crops, rice is the mainstay of the sustenance of Asia's population since long. Therefore, smart rice research is needed to make the rice production systems economically and ecologically sustainable. Weeds are known to be a major biotic constraint in agricultural production systems. Of the total annual loss of agricultural produce from various pests in India, weeds accounts for $45 \%$, insect $30 \%$, diseases $20 \%$ and other pests $5 \%$ (Rao, 1983). In India, yield loss due to weeds in transplanted rice was estimated to the tune of $30.9 \%$ over weedy check (AICRP-weed management, 2003-2012). Considering the diversity and complexity of weed problem, it can be stated that no single method of weed control whether cultural, manual, mechanical or chemical would be sufficient to provide season-long sustainable weed management under transplanted rice ecosystem. In the above-mentioned perspective, a field experiment on weed management in 'Mashuri' cultivar of rice was carried out at Uttar Banga Krishi Viswavidyalaya, Pundibari, Cooch Behar, West Bengal during kharif season of 2016. The experiment was laid out in randomized block design having 12 treatments replicated thrice: $\mathrm{T}_{1}-$ Weedy check; $\mathrm{T}_{2}-$ Weed free; $\mathrm{T}_{3}-\mathrm{PW}$ at 15,30 and 45 DAT; $\mathrm{T}_{4}-$ Metsulfuron methyl 20\% WP @ $8 \mathrm{~g}$ a.i. ha ${ }^{-1}$ at $10 \mathrm{DAT} ; \mathrm{T}_{5}-$ Bispyribac sodium $10 \%$ SC @ $20 \mathrm{~g}$ a.i. ha ${ }^{-1}$ at 14 DAT; $\mathrm{T}_{6}-$ Bispyribac sodium $10 \% \mathrm{SC} @ 30 \mathrm{~g}$ a.i. ha ${ }^{-1}$ at $14 \mathrm{DAT}$; $\mathrm{T}_{7}$ - Pretilachlor $0.60 \mathrm{~kg}$ a.i. ha ${ }^{-1}+\mathrm{PW}$ at 25 and $40 \mathrm{DAT}$; $\mathrm{T}_{8}-$ Pretilachlor $0.60 \mathrm{~kg} \mathrm{a.i.} \mathrm{ha}^{-1}+2,4-\mathrm{D}$ $0.50 \mathrm{~kg}$ a.i. $\mathrm{ha}^{-1}$ at $30 \mathrm{DAT}+\mathrm{PW}$ at $45 \mathrm{DAT} ; \mathrm{T}_{9}-$ Pretilachlor $0.60 \mathrm{~kg}$ a.i. ha ${ }^{-1}+$ Bispyribac sodium $10 \%$ SC @ $20 \mathrm{~g}$ a.i. ha ${ }^{-1}$ at 22-25 DAT + PW at $40 \mathrm{DAT} ; \mathrm{T}_{10}-$ Bispyribac sodium $10 \% \mathrm{SC} @ 20 \mathrm{~g}$ a.i. $\mathrm{ha}^{-1}$ at $20 \mathrm{DAT}+\mathrm{PW}$ at $40 \mathrm{DAT} ; \mathrm{T}_{11}-2,4-\mathrm{D} 0.50 \mathrm{~kg}$ a.i. ha ${ }^{-1}$ at $25 \mathrm{DAT}+\mathrm{PW}$ at $40 \mathrm{DAT}$ and $\mathrm{T}_{12}$ - Pretilachlor $0.60 \mathrm{~kg}$ a.i. ha ${ }^{-1}+$ Metsulfuron methyl $20 \% \mathrm{WP} @ 8 \mathrm{~g}$ a.i. ha ${ }^{-1}$ at $10 \mathrm{DAT}$. It was evident from the results that almost all the growth and yield attributes, weed population (no $\mathrm{m}^{-2}$ ), dry weight of weeds $\left(\mathrm{g} \mathrm{m}^{-2}\right)$, WCE, WCI and WI differed significantly with different weed management practices. So far as growth components and yield attributes were concerned, $\mathrm{T}_{2}$ i.e. weed free exhibited the best performance closely followed and in some cases being at par with $\mathrm{T}_{9}$. Highest grain yield $\left(4.23 \mathrm{tha}^{-1}\right)$ was achieved from weed free being at par with $\mathrm{T}_{9}\left(4.14 \mathrm{t} \mathrm{ha}^{-1}\right)$ but differed significantly from others. Apart from weed free treatment, highest WCE \& WCI was achieved from $\mathrm{T}_{9}$. Excepting $\mathrm{T}_{2}$ lowest weed index at harvest $(1.72 \%)$ was also achieved from $\mathrm{T}_{9}$. As far as the production economics was concerned, highest gross return (Rs. 68541.00/ha) was obtained from $\mathrm{T}_{2}$ followed by $\mathrm{T}_{9}$ (Rs. 67198.00/ha). But in case of net return, highest value of Rs. 29223.00 was obtained from $T_{9}$ and due to its high cost of cultivation $T_{6}$ showed highest input: output ratio (1:1.80) narrowly followed by $T_{9}(1: 1.77)$. So, it was concluded that the treatment $T_{6}$ or $T_{9}$ could be opted for sufficient control of weeds in transplanted kharif paddy in terai zone of West Bengal to maximize the economic return. 


\section{Introduction}

Rice (Oryza sativa L.) is the main source of food for more than half of the world population, especially in South and Southeast Asia and Latin America. Rice is cultivated in 114 countries across the world. The global production of rice has been estimated to be 697.22 million tons of rice with an average yield of $4.4 \mathrm{t} \mathrm{ha}^{-1}$ being harvested from 158.43 million ha annually producing $21 \%$ of world's food calorie supply. Asia is the leader in rice production accounting for about 90 per cent of the world's production. Over 75 per cent of the world supply is consumed by people in Asian countries and thus rice is of immense importance to food security of Asia.

Rice occupies a pivotal place in Indian agriculture and is the staple food for more than 65 per cent of the Indian population, accounting for more than 43 per cent of total food grain production and 55 per cent of cereals production in the country. By the year 2030, the demand for rice in our country will increase up to 122 million tons. This yield target is possible to achieve with the adoption of improved rice production technology (Anonymous, 2011).

West Bengal occupies the second position in terms of area (5.38 $\mathrm{M}$ ha) and first position in terms of production $(14.71 \mathrm{Mt})$ of rice in India with a productivity level of $2.73 \mathrm{t} \mathrm{ha}^{-1}$. In West Bengal, $75 \%$ of total area under rice cultivation is covered by aman (kharif) transplanted rice.

The global annual demand for rice is expected to be around 800 million tons by 2025 in view of the expected increase in population. Therefore, smart rice research is needed to make the rice production systems economically and ecologically sustainable. Weeds are known to be a major biotic constraint in agricultural production systems.
Of the total annual loss of agricultural produce from various pests in India, weeds accounts for $45 \%$, insect $30 \%$, diseases $20 \%$ and other pests 5\% (Rao, 1983). Annually, 15 million tons of rice is reported to be lost due to weeds in India (Chatterjee and Maiti, 1981). Yield loss due to uncontrolled weed growth in transplanted rice ranges from 12 to $51 \%$ (DDR, 1990). In India, yield loss due to weeds in transplanted rice was estimated to the tune of $30.9 \%$ over weedy check (AICRP-weed management, 2003-2012).

Weeds reduce the potential production of rice by interfering with agricultural operations. The average yield of rice in India is very low due to several constrains. Among them, weeds pose a major threat for increasing rice productivity. Uncontrolled weed growth caused 33-45\% reduction in grain yield of rice (Singh et al., 2007; Manhas et al., 2012). Any delay in weeding will lead to increased weed biomass as a result drastic reduction in yield.

A study at Directorate of Weed Science Research reveals that nearly one third of oilseeds, half of the food grains and equal amount of pulses produced currently are lost due to weeds and proper weed management technologies if adopted can result in additional production of 103 million tons of food grains, 15 million tons of pulses, 10 million tons of oilseeds and 52 million tons of commercial crops per annum. This amounts to an additional income of rupees 105036 crores per annum (NRCWS, 2007 and Varshney and Prasad Babu, 2008).

It is well known fact that weed management through manual hand weeding is most efficient and safe but high physical energy and cost involvement make it difficult for its timely implication in large area. In addition, shortage of labour supply during the peak period and high wages force the farmers to neglect weed management practices. Recently, 
due to this problem, chemical weed management is getting pace. However, in the long run, chemical weed management may not be sustainable and cause environmental hazards. Considering the diversity and complexity of weed problem, it can be stated that no single method of weed control whether cultural, manual, mechanical or chemical would be sufficient to provide season-long sustainable weed management under transplanted rice ecosystem. Therefore, integration of other weed management practices along with chemical management should be advocated in the present scenario for increasing crop production.

\section{Materials and Methods}

\section{Experimental site}

Keeping the above ideas in view, the research work was planned and conducted on 'Mashuri' cultivar of rice during the kharif season (2016) at instructional farm of Uttar Banga Krishi Viswavidyalaya, Pundibari, Cooch Behar, West Bengal to find out an effective method of weed management in transplanted rice in terai zone of West Bengal. The farm is situated at $26^{0} 19^{\prime} 86^{\prime}$ 'N latitude and $89^{\circ} 23$ ' $53^{\prime \prime}$ E longitude, at an elevation of 43 meter above mean sea level. The topography of the land where the experiment is under taken is medium in situation endowed with good drainage facility. The texture of soil of the experimental field is sandy loam. The average rainfall of this zone varies between 2100 to $3300 \mathrm{~mm}$. The maximum rainfall, i.e., about $80 \%$ of the total, is received from southwest monsoon during the rainy months from June to September. Minimum and maximum mean temperature of this region varies in between $21.72^{\circ} \mathrm{C}$ and $34.16^{\circ} \mathrm{C}$ respectively during the experimental season. Minimum and maximum relative humidity of $74.32 \%$ and $93.26 \%$ respectively are recorded during the period of experimentation.

\section{Agro-climatic condition of Terai zone}

The climatic condition of terai zone is subtropical in nature with eminent characteristics of high rainfall, high humidity and prolonged winter season. In this zone, there are two distinctive seasons in a year- a much extended winter or dry rabi season and a long rainy season. The winter season starts from middle of October with fall in night temperature and is extended up to March with the same range of low night temperature, very light rainfall, cool temperature, high humidity and dry clean sunny days.

Another is wet or rainy season characterized by hot and humid weather, heavy rain fall brought about by south-west monsoon with cloudy overcast days and fewer hours of bright sunshine. The crop growing seasons of this zone are broadly classified as Pre-kharif (dry and warm) starting from March to May, Kharif (wet and warm) starting from June to October and Rabi (dry and cool) during November to February. The rainy season starts from $2^{\text {nd }}$ fortnight of May and sometime it appears during $1^{\text {st }}$ week of June. Rainy season continues up to last week of September. In addition to this, a light shower occurs during the first fortnight of April followed by a dry spell up to the onset of monsoon. The average rainfall of this zone varies between 2100 to $3300 \mathrm{~mm}$. The maximum rainfall, i.e., about $80 \%$ of the total, is received from south-west monsoon during the rainy months from June to September (Fig. 1-4).

\section{Experimental design with treatment details}

The experiment was laid out in a Randomized Block Design (RBD) with 12 treatments replicated thrice giving a total of 36 unit plots each measuring $6.0 \mathrm{~m} \times 4.0 \mathrm{~m}$ (24 sq. meter). The treatments were $\mathrm{T}_{1}-$ Weedy check; $\mathrm{T}_{2}-$ Weed free; $\mathrm{T}_{3}$ - Paddy weeder at 15, 30 and 45 DAT; $T_{4}-$ Metsulfuron methyl 20\% WP @ 
8 g a.i. ha $^{-1}$ (Formulation $40 \mathrm{ml} . \mathrm{ha}^{-1}$ ) at 10 DAT; $\mathrm{T}_{5}-$ Bispyribac sodium 10\% SC @ $20 \mathrm{~g}$ a.i. ha ${ }^{-1}$ (Formulation $200 \mathrm{ml}^{\text {ha }} \mathrm{ha}^{-1}$ ) at 14 DAT; $\mathrm{T}_{6}$ - Bispyribac sodium 10\% SC @ $30 \mathrm{~g}$ a.i. ha $^{-1}$ (Formulation $300 \mathrm{ml} . \mathrm{ha}^{-1}$ ) at $14 \mathrm{DAT}$; $\mathrm{T}_{7}$ - Pretilachlor $0.60 \mathrm{~kg}$ a.i. $\mathrm{ha}^{-1}+$ Paddy weeder at 25 and 40 DAT; $\mathrm{T}_{8}-$ Pretilachlor $0.60 \mathrm{~kg}$ a.i. $\mathrm{ha}^{-1}+2,4-\mathrm{D} 0.50 \mathrm{~kg}$ a.i. $\mathrm{ha}^{-1}$ at $30 \mathrm{DAT}+$ Paddy weeder at 45 DAT; $\mathrm{T}_{9}-$ Pretilachlor $0.60 \mathrm{~kg}$ a.i. $\mathrm{ha}^{-1}+$ Bispyribac sodium $10 \%$ SC @ $20 \mathrm{~g}$ a.i. $\mathrm{ha}^{-1}$ at 22-25 DAT (Formulation $\left.200 \mathrm{ml} . \mathrm{ha}^{-1}\right)+$ Paddy weeder at 40 DAT; $\mathrm{T}_{10}$ - Bispyribac sodium 10\% SC @ $20 \mathrm{~g}$ a.i. ha ${ }^{-1}$ (Formulation $200 \mathrm{ml} . \mathrm{ha}^{-1}$ ) at $20 \mathrm{DAT}+$ Paddy weeder at $40 \mathrm{DAT} ; \mathrm{T}_{11}-2,4-\mathrm{D} 0.50 \mathrm{~kg}$ a.i. $\mathrm{ha}^{-1}$ at $25 \mathrm{DAT}+$ Paddy weeder at $40 \mathrm{DAT}$ and $\mathrm{T}_{12}-$ Pretilachlor $0.60 \mathrm{~kg}$ a.i. $\mathrm{ha}^{-1}+$ Metsulfuron methyl 20\% WP @ 8 g a.i. ha ${ }^{-1}$ (Formulation $40 \mathrm{ml} . \mathrm{ha}^{-1}$ ) at $10 \mathrm{DAT}$.

The amount of herbicide required for each plot was calculated on the basis of the following formula.

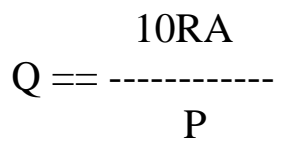

Where,

$\mathrm{Q}=$ Quantity of herbicide required in gm or $\mathrm{ml}$.

$\mathrm{R}=$ Rate of application in $\mathrm{kg} \mathrm{ha}^{-1}$

$\mathrm{A}=$ Area in $\mathrm{m}^{-2}$

$\mathrm{P}=$ Percentage of active ingredient in commercial formulation.

Water required to make a spray volume of herbicide was determined through calibration technique in which flood jet nozzle was used for. A thin film of water was maintained at the time of herbicide application. Paddy weeder was operated as per the treatment schedule.
All other agronomic and plant protection measures were adopted as per the recommended packages.

\section{Biometric observations}

The observations for various growth attributes such as number of tillers per square meter; plant height; dry matter accumulation etc. were recorded from the earmarked area through destructive sampling.

From those observations, crop growth rate (CGR) and relative growth rate (RGR) were worked out. Yield attributes such as number of panicles $\mathrm{m}^{-2}$, number of filled grains panicle ${ }^{-1}$, test weight (1000 grain weight) in g., grain yield $\left(\mathrm{t} \mathrm{ha}{ }^{-1}\right)$, straw yield $\left(\mathrm{t} \mathrm{ha}^{-1}\right)$ and harvest index $(\%)$ were recorded at the time of maturity. Weed flora composition (No. $\mathrm{m}^{-2}$ ), Dry weight of weeds $\left(\mathrm{g} \mathrm{m}^{-2}\right)$ was also recorded and accordingly Weed control efficiency (WCE \%), Weed control index (WCI \%), Weed index (WI \%) were worked out as per standard formula.

$$
\begin{gathered}
\mathrm{WD}_{\mathrm{C}}-\mathrm{WD}_{\mathrm{T}} \\
\text { Weed control efficiency }(\mathrm{WCE})=-----\mathrm{X} 100 \\
\mathrm{WD}_{\mathrm{C}}
\end{gathered}
$$

Where,

$\mathrm{WD}_{\mathrm{C}}=$ Weed density (number $\mathrm{m}^{-2}$ ) in weedy check/control plot.

$\mathrm{WD}_{\mathrm{T}}=$ Weed density (number $\mathrm{m}^{-2}$ ) in treated plot.

$\mathrm{WDM}_{\mathrm{C}}-\mathrm{WDM}_{\mathrm{T}}$
Weed control index $(\mathrm{WCI})=\frac{-------\mathrm{X} 100}{\mathrm{WDM}_{\mathrm{C}}}$

Where,

$\mathrm{WDM}_{\mathrm{C}}=$ Weed dry weight (unit $\mathrm{m}^{-}{ }^{2}$ ) in control plot. 
$\mathrm{WDM}_{\mathrm{T}}=$ Weed dry weight (unit $\mathrm{m}^{2}$ ) in treated plot.

Weed Index $(\mathrm{WI})=\frac{\mathrm{Y}_{\mathrm{WF}}-\mathrm{Y}_{\mathrm{T}}}{-----\mathrm{X} 100}$

Where,

$\mathrm{Y}_{\mathrm{WF}}=$ Yield of the crop in weed free plot.

$\mathrm{Y}_{\mathrm{T}}=$ Yield of the crop in treatment plot.

\section{Statistical analysis}

The data obtained from the experiment were subjected to statistical analysis by the Analysis of Variance method (Gomez and Gomez, 1984) and the significance of different sources of variations were tested by Error Mean Square by Fisher and Snedecor's ' $F$ ' test at probability level 0.05 . For determination of critical difference at $5 \%$ level of significance, Fisher and Yate's table (Fisher and Yate's, 1963) was consulted.

\section{Economic analysis}

The cost of cultivation, gross return, net return and return per rupee invested of different treatments were calculated and the cost of various inputs like seeds, fertilizers, herbicides and all other inputs including labour charges were estimated as per price of the items in the market. The value of products like grain and straw was also calculated on the basis of available price at the market.

\section{Results and Discussion}

\section{Weed flora}

In the experimental field Cynodon dactylon, Echinochloa crus-galli, Echinochloa colona, and Digitaria sanguinalis under grasses; Cyperus difformis, Cyperus rotundus, Cyperus iria and Fimbristylis miliacea under sedges and Ammania baccifera, Commelina benghalensis, Eclipta prostrate, Ludwigia parviflora, Monochoria vaginalis and Marsilea quadrifolia under broad-leaved weeds were observed.

\section{Weed dry weight, Weed control efficiency, weed control index and weed index}

Weed dry weight was recorded at $0,30,45$ and 60 DAT from different weed management treatments. The lowest $(0.00)$ weed dry weight was recorded with weed free treatment $\left(T_{2}\right)$ and highest weed dry weight was recorded with weedy check $\left(T_{1}\right)$ at all the stages of crop growth i.e. 30, 45 and 60 DAT. Among the herbicide combination treatments lowest weed dry weight $\left(1.00,2.89\right.$ and $\left.3.40 \mathrm{~g} \mathrm{~m}^{-2}\right)$ was recorded with pretilachlor $0.60 \mathrm{~kg}$ a.i ha ${ }^{-1}+$ bispyribac sodium 10\% SC @ $20 \mathrm{~g}$ a.i ha ${ }^{-1}$ at 22-25 DAT + paddy weeder at $40 \mathrm{DAT}\left(\mathrm{T}_{9}\right)$ followed by bispyribac sodium 10\% SC @ 20 g a.i ha ${ }^{-1}$ at 20 DAT + paddy weeder at 40 DAT i.e. $\mathrm{T}_{10}\left(1.25,3.20\right.$ and $\left.3.97 \mathrm{~g} \mathrm{~m}^{-2}\right)$, bispyribac sodium 10\% SC @ $30 \mathrm{~g}$ a.i ha ${ }^{-1}$ at 14 DAT i.e. $\mathrm{T}_{6}\left(1.45,3.37\right.$ and $\left.4.10 \mathrm{~g} \mathrm{~m}^{-2}\right)$ and bispyribac sodium 10\% SC @ $20 \mathrm{~g}$ a.i ha ${ }^{-1}$ at 14 DAT i.e. $\mathrm{T}_{5}\left(1.78,4.51\right.$ and $\left.4.34 \mathrm{~g} \mathrm{~m}^{-2}\right)$ at all the crop growth periods i.e. 30, 45 and 60 DAT respectively (Table 1 ).

Weed control efficiency (WCE) and weed control index (WCI) both were found higher $(100 \%)$ in $\mathrm{T}_{2}$ i.e. weed free and lower $(0 \%)$ in $\mathrm{T}_{1}$ i.e. weedy check. Among the treatments excepting $\mathrm{T}_{2}$ and $\mathrm{T}_{1}$, the highest weed control efficiency at $30(87.18 \%), 45(90.91 \%)$ and $60(89.54 \%)$ DAT was registered with pretilachlor $0.60 \mathrm{~kg}$ a.i $\mathrm{ha}^{-1}+$ bispyribac sodium 10\% SC @ $20 \mathrm{~g} \mathrm{a} . \mathrm{i} \mathrm{ha}{ }^{-1}$ at 22-25 DAT + paddy weeder at 40 DAT $\left(\mathrm{T}_{9}\right)$ (Table 1 , Figure 5 and 6).

Weed index indicated percentage of crop yield reduction by weeds. The maximum weed index value $(52.25 \%)$ was recorded in the 
treatment weedy check $\left(\mathrm{T}_{1}\right)$ and minimum weed index value $(0.00 \%)$ was observed in the treatment weed free $\left(\mathrm{T}_{2}\right)$ (Table 1 and Figure 7).

\section{Growth attributes of rice}

Data exhibited that plant height at all stages of crop growth i.e. 30, 60, 90 DAT and at maturity differed significantly with different weed management practices adopted in the experimentation. At all stages, the treatment $\mathrm{T}_{2}$ i.e. weed free performed the best. During almost all the growth stages, $\mathrm{T}_{2}$ was closely followed and at par with the rest of the treatments barring $\mathrm{T}_{1}$ i.e. control plot. $\mathrm{T}_{9}$ i.e. pretilachlor $0.60 \mathrm{~kg}$ a.i. $\mathrm{ha}^{-1}+$ bispyribac sodium 10\% SC @ $20 \mathrm{~g}$ a.i. ha ${ }^{-1}$ at 22-25 DAT + Paddy weeder at 40 DAT obtained the second highest result at later stages of crop growth. The lowest plant height was observed in $\mathrm{T}_{1}$ i.e. weedy check at all stages of the crop.

It was evident that the number of tiller $\mathrm{m}^{-2}$ at 30, 60, 90 DAT differed significantly with different weed management practices in rice. At all stages of crop growth, $T_{2}$ i.e. weed free treatment registered highest number of tillers $\mathrm{m}^{-2}$ being statistically at par with $\mathrm{T}_{9}$ i.e. Pretilachlor $0.60 \mathrm{~kg}$ a.i $\mathrm{ha}^{-1}+$ bispyribac sodium 10\% SC @ $20 \mathrm{~g}$ a.i ha ${ }^{-1}$ at 22-25 DAT + paddy weeder at 40 DAT but significantly differed from all other treatments. $\mathrm{T}_{9}$ was followed by $\mathrm{T}_{10}$ i.e. Bispyribac sodium $10 \%$ SC @ $20 \mathrm{~g} \mathrm{a.i} \mathrm{ha}^{-1}$ at $20 \mathrm{DAT}+$ paddy weeder at 40 DAT and $\mathrm{T}_{6}$ i.e. Bispyribac sodium $10 \%$ SC @ $30 \mathrm{~g}$ a.i ha ${ }^{-1}$ at 14 DAT. The lowest number of tillers $\mathrm{m}^{-2}$ was recorded with weedy check $\left(\mathrm{T}_{1}\right)$ at all stages of crop growth (Table 2).

It was reflected that there was significant difference in between various weed management practices with regard to the dry matter accumulation of total plant in $\mathrm{g} \mathrm{m}^{-2}$ at 30, 60 and $90 \mathrm{DAT}$. At 30 and $90 \mathrm{DAT}, \mathrm{T}_{2}$ i.e. weed free treatment registered highest dry matter accumulation by rice crop being significantly different from all other treatments. $\mathrm{T}_{9}$ i.e. Pretilachlor $0.60 \mathrm{~kg}$ a.i ha ${ }^{-1}$ + bispyribac sodium 10\% SC @ $20 \mathrm{~g} \mathrm{a} . \mathrm{i} \mathrm{ha}^{-1}$ at 22-25 DAT + paddy weeder at 40 DAT and $\mathrm{T}_{10}$ i.e. Bispyribac sodium 10\% SC @ 20 g a.i $\mathrm{ha}^{-1}$ at $20 \mathrm{DAT}+$ paddy weeder at $40 \mathrm{DAT}$ recorded second and third best performances. At $60 \mathrm{DAT}, \mathrm{T}_{2}$ was at par with $\mathrm{T}_{9}$ but different from rest others. At all stages of crop growth, the lowest dry matter accumulation was recorded with weedy check $\left(\mathrm{T}_{1}\right)$ (Table 2$)$.

\section{Growth functions of rice}

Data revealed that there was significant difference in crop growth rate $\left(\mathrm{g} \mathrm{m}^{-2} \mathrm{~d}^{-1}\right)$ at 30-60 DAT and 60-90 DAT due to the effect of different weed management practices. At 30-60 DAT, the maximum crop growth rate (24.42 $\left.\mathrm{g} \mathrm{m}^{-2} \mathrm{~d}^{-1}\right)$ was recorded with $\mathrm{T}_{8}$ i.e. Pretilachlor $0.60 \mathrm{~kg}$ a.i $\mathrm{ha}^{-1}+2,4-\mathrm{D} 0.50 \mathrm{~kg}$ a.i $\mathrm{ha}^{-1}$ at $30 \mathrm{DAT}+$ paddy weeder at $45 \mathrm{DAT}$ being statistically at par with and closely followed by $\mathrm{T}_{7}, \mathrm{~T}_{9}, \mathrm{~T}_{2}, \mathrm{~T}_{3}, \mathrm{~T}_{11}, \mathrm{~T}_{5}$ and $\mathrm{T}_{6}$. The lowest crop growth rate was observed in $T_{1}$ i.e. weedy check $\left(19.50 \mathrm{~g} \mathrm{~m}^{-2} \mathrm{~d}^{-1}\right)$. At $60-90$ DAT, $\mathrm{T}_{10}$ i.e. Bispyribac sodium 10\% SC @ $20 \mathrm{~g}$ a.i ha ${ }^{-1}$ at $20 \mathrm{DAT}+$ paddy weeder at 40 DAT showed the highest crop growth rate (33.70 $\mathrm{g} \mathrm{m}^{-2} \mathrm{~d}^{-1}$ ) being at par with $\mathrm{T}_{12}$ (31.83), $\mathrm{T}_{9}$ (31.30), $\mathrm{T}_{6}$ (31.98), $\mathrm{T}_{4}$ (33.00), $\mathrm{T}_{2}$ (32.61) and $\mathrm{T}_{1}$ (32.92). The lowest value $\left(28.81 \mathrm{~g} \mathrm{~m}^{-2}\right.$ $\mathrm{d}^{-1}$ ) was observed in $\mathrm{T}_{5}$ i.e. Bispyribac sodium 10\% SC @ 20 g a.i ha ${ }^{-1}$. At 30-60 DAT, maximum relative growth rate was recorded to the tune of $0.014 \mathrm{~g} \mathrm{~g}^{-1} \mathrm{~d}^{-1}$ from the treatments $\mathrm{T}_{5}, \mathrm{~T}_{7}, \mathrm{~T}_{8}$ and $\mathrm{T}_{11}$. Lowest relative growth rate $\left(0.012 \mathrm{~g} \mathrm{~g}^{-1} \mathrm{~d}^{-1}\right)$ was observed in the treatments $\mathrm{T}_{1}, \mathrm{~T}_{2}, \mathrm{~T}_{4}$ and $\mathrm{T}_{10}$. At 60-90 DAT, maximum relative growth rate was recorded to the tune of $0.014 \mathrm{~g} \mathrm{~g}^{-1} \mathrm{~d}^{-1}$ from the treatments $\mathrm{T}_{1}$ and $\mathrm{T}_{4}$. Lowest relative growth rate $\left(0.011 \mathrm{~g} \mathrm{~g} \mathrm{~g}^{-1}\right.$ $\mathrm{d}^{-1}$ ) was observed in the treatments $\mathrm{T}_{5}$ and $\mathrm{T}_{9}$ (Table 2). 
Meteorological monthly mean data pertaining to the period of experiments from May, 2016 to October, 2016

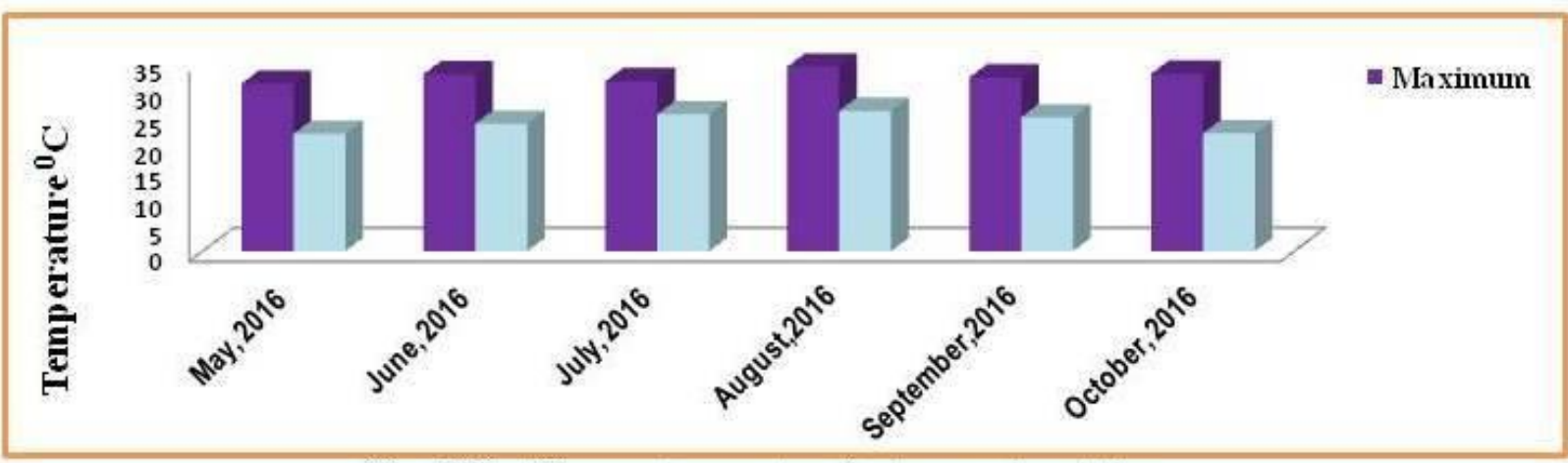

Fig.: 1 Monthly mean temperature during experimentation

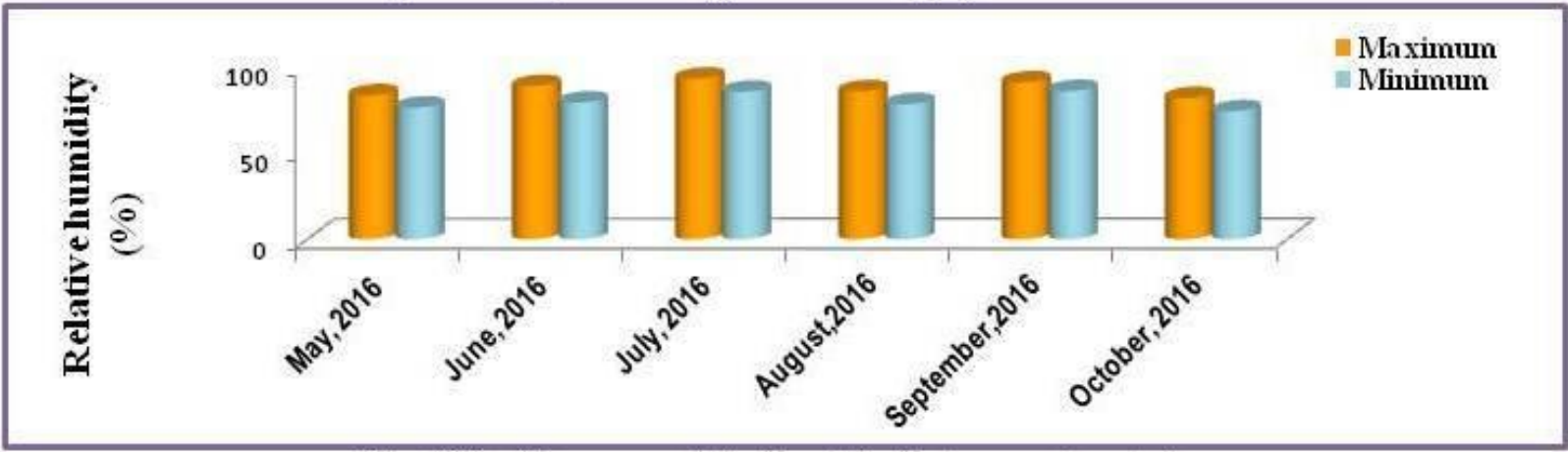

Fig.: 2 Monthly mean r elative humidity during experimentation

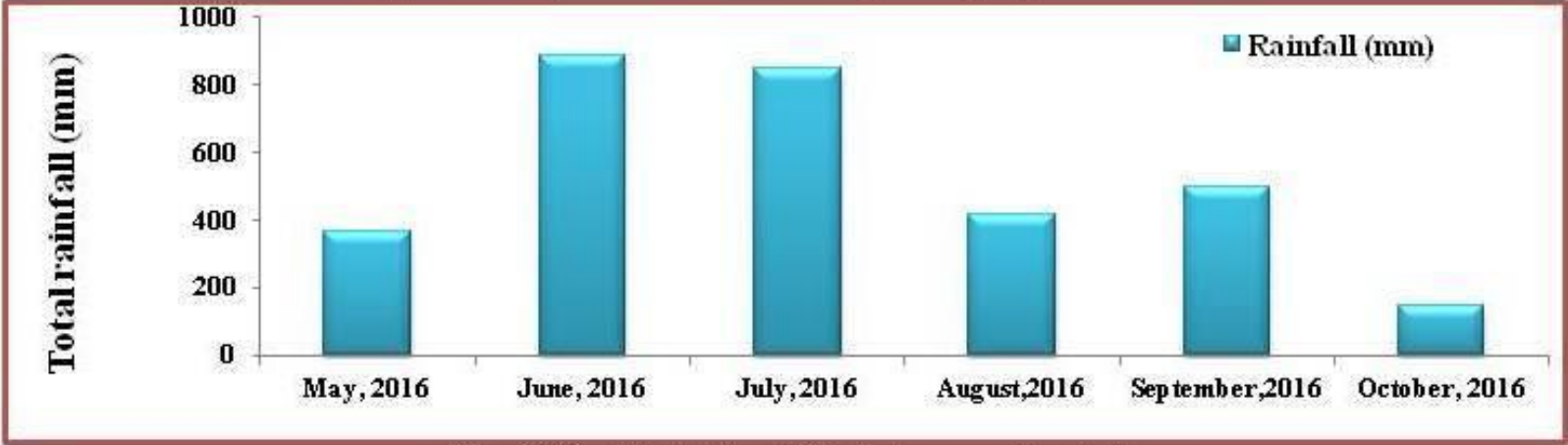

Fig.: 3 Montlly total rainfall during experimentation

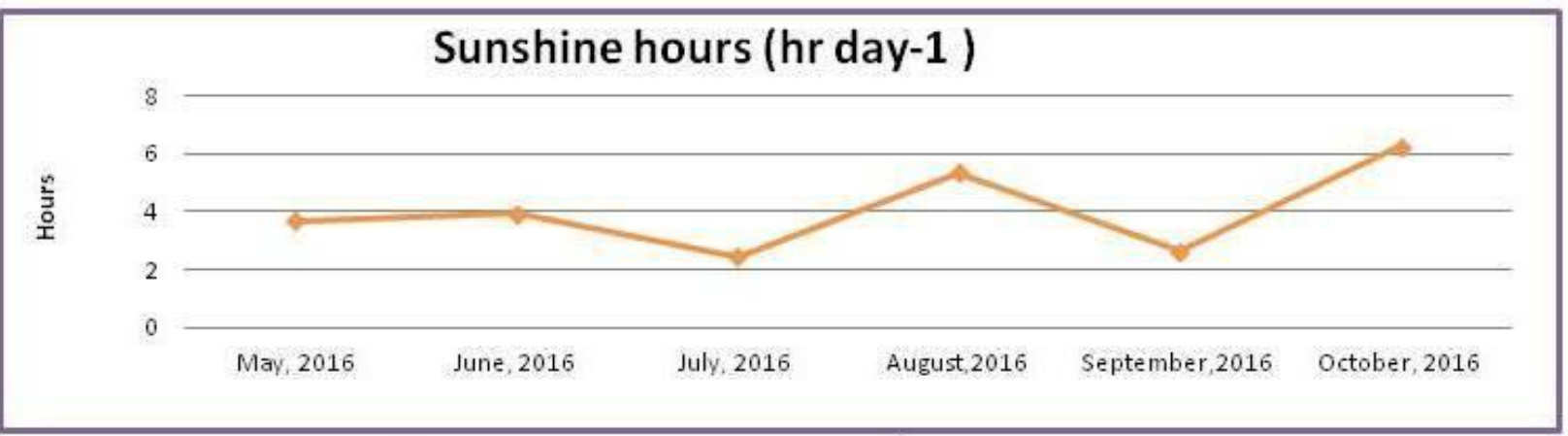

Fig.: 4 Monthly mean sunshine hours day ${ }^{-1}$ during experimentation 


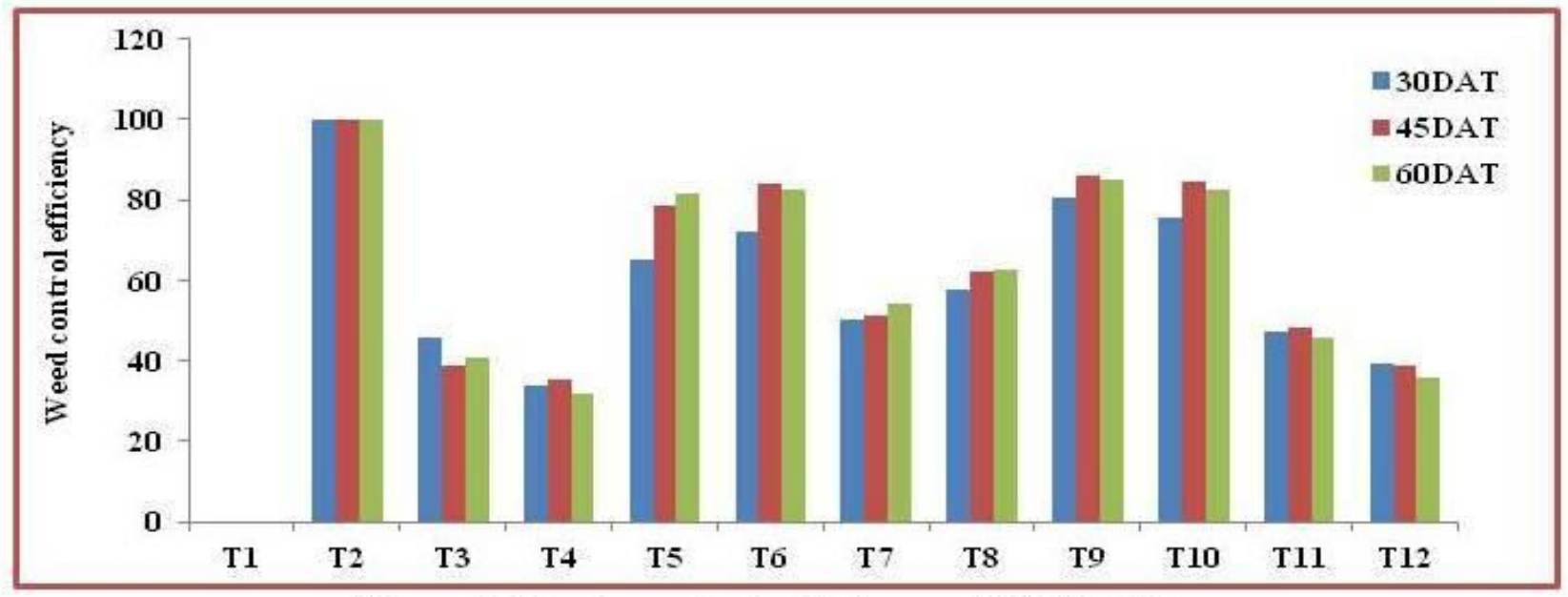

Fig. : 5 Weed control efficiency (WCE \%)

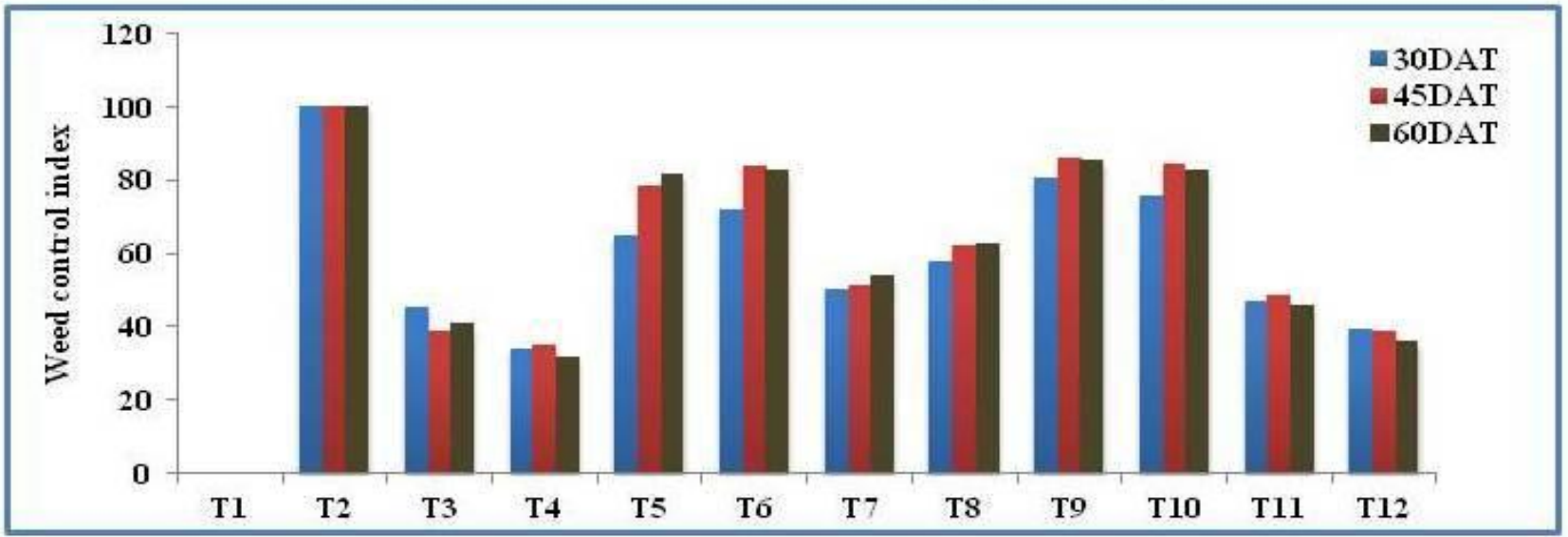

Fig. : 6 Weed control index (WCI \%)

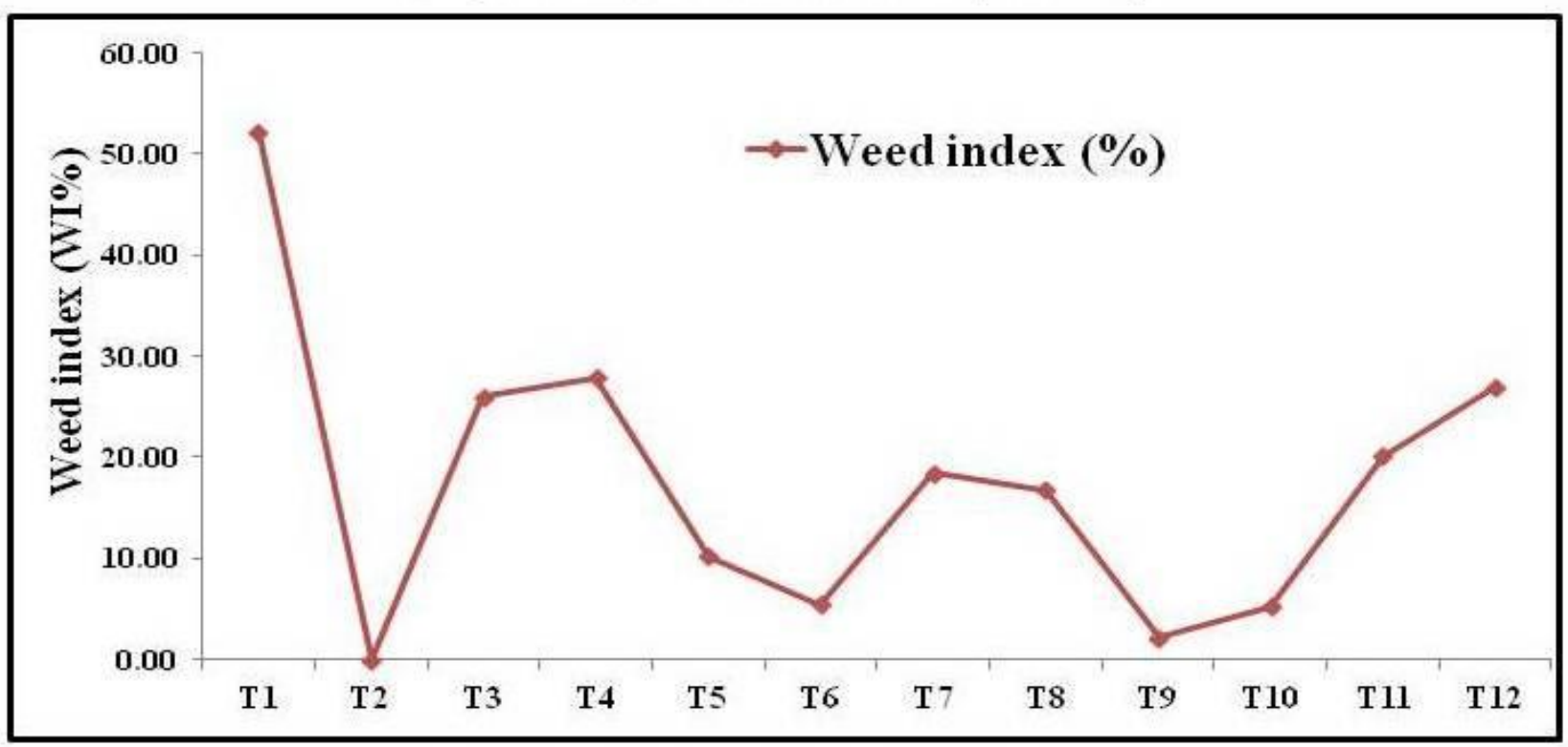

Fig. : 7 Weed index (at harvest) 


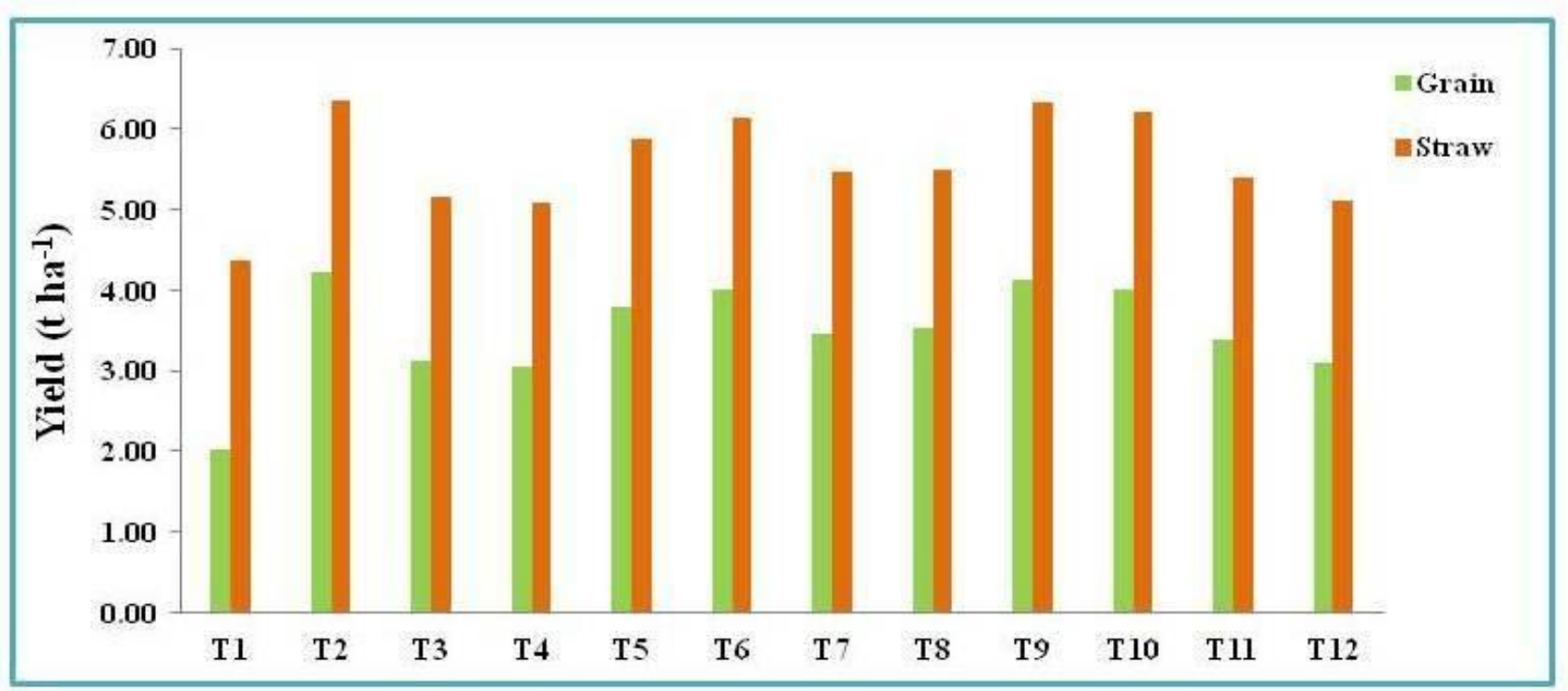

Fig. : 8 Grain yield and Straw yield $\left(\mathrm{tha}^{-1}\right)$

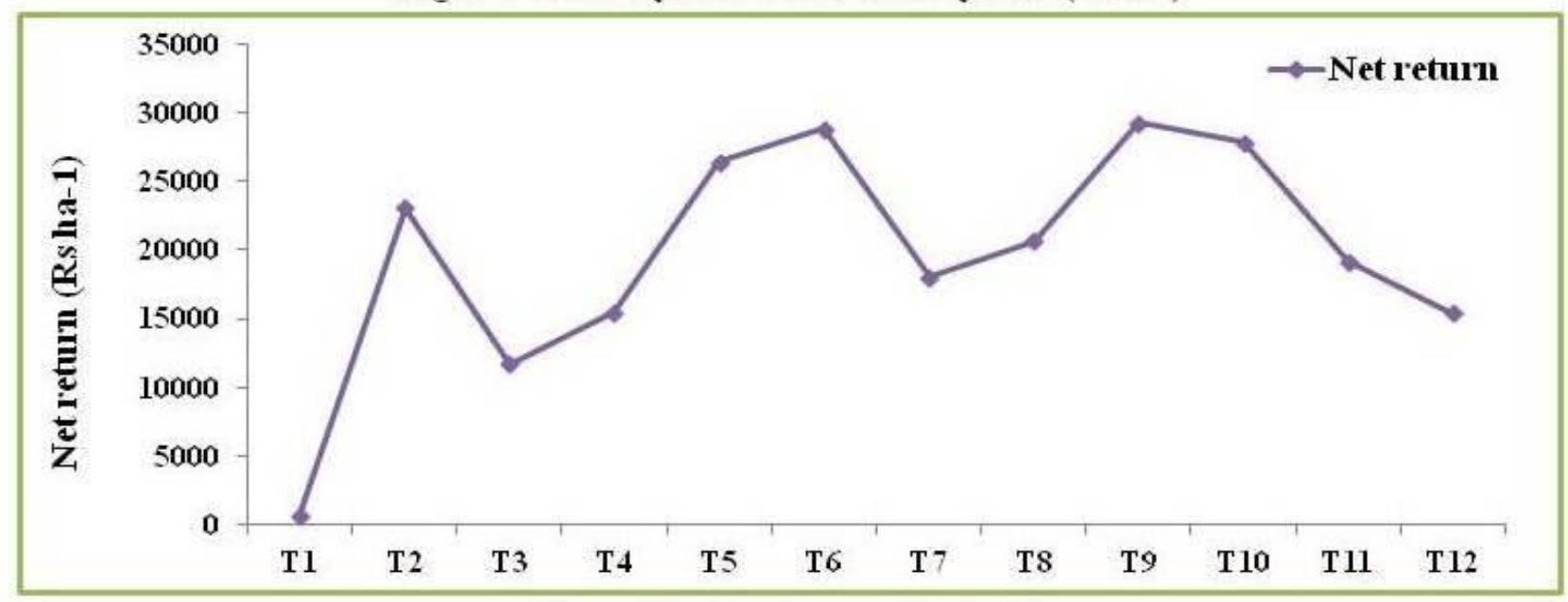

Fig. : 9 Net return (Rs ha-1)

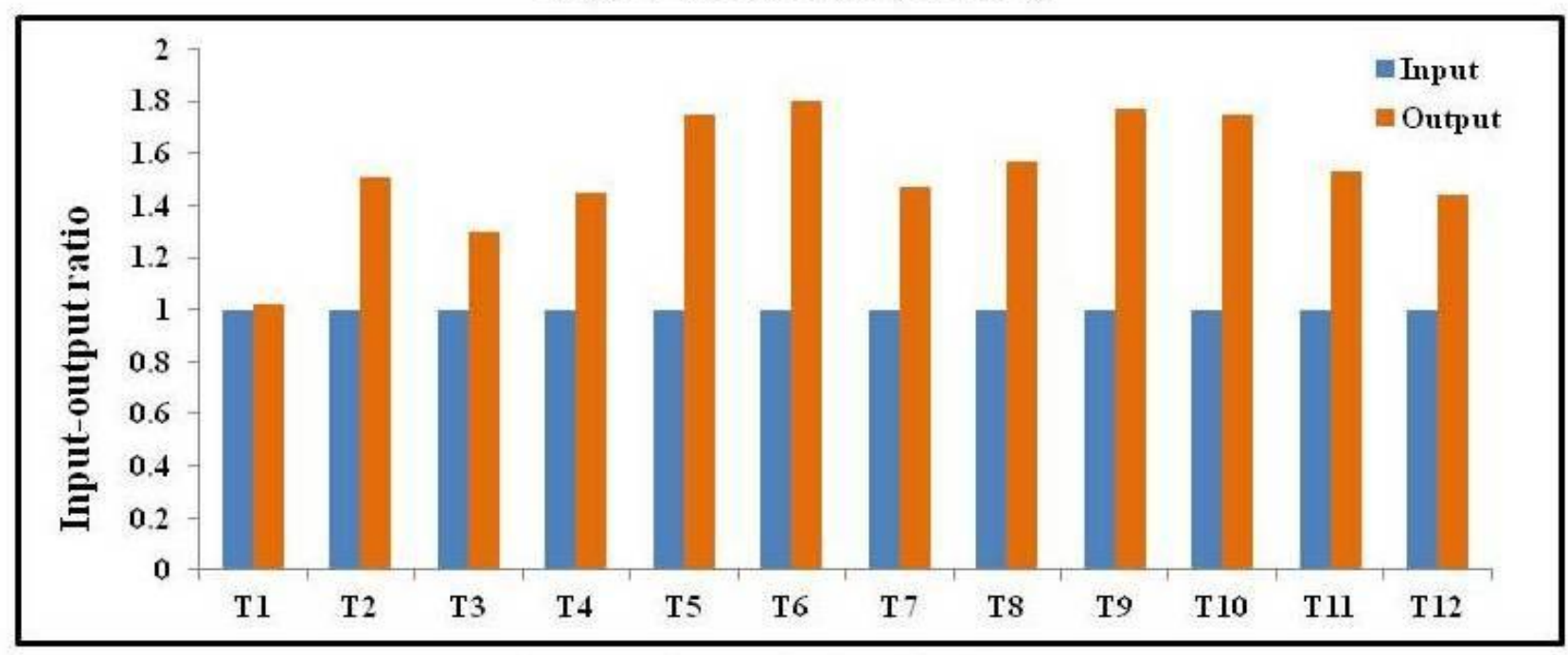

Fig. : 10 Input-output ratio 
Table.1 Effect of weed management practices on weed dry weight, weed control efficiency, weed control index and weed index

\begin{tabular}{|c|c|c|c|c|c|c|c|c|c|c|}
\hline \multirow[t]{2}{*}{ Treatment } & \multicolumn{3}{|c|}{ Weed dry weight $\left(\mathrm{g} \mathrm{m}^{-2}\right)$} & \multicolumn{3}{|c|}{$\begin{array}{c}\text { Weed control efficiency (WCE } \\
\% \text { ) }\end{array}$} & \multicolumn{3}{|c|}{ Weed control index (WCI \%) } & \multirow{2}{*}{$\begin{array}{l}\text { Weed index } \\
\text { At harvest }\end{array}$} \\
\hline & 30DAT & 45DAT & 60DAT & 30DAT & 45DAT & 60DAT & 30DAT & 45DAT & 60DAT & \\
\hline $\mathbf{T}_{1}$ & 5.18 & 21.06 & 23.76 & 0.00 & 0.00 & 0.00 & 0.00 & 0.00 & 0.00 & 52.25 \\
\hline $\mathbf{T}_{2}$ & 0.00 & 0.00 & 0.00 & 100.00 & 100.00 & 100.00 & 100.00 & 100.00 & 100.00 & 0.00 \\
\hline $\mathbf{T}_{3}$ & 2.80 & 12.82 & 13.87 & 57.16 & 52.25 & 51.19 & 45.68 & 38.92 & 40.58 & 26.00 \\
\hline $\mathbf{T}_{4}$ & 3.41 & 13.58 & 15.87 & 43.41 & 42.02 & 39.72 & 33.92 & 35.24 & 31.85 & 27.90 \\
\hline $\mathbf{T}_{\mathbf{5}}$ & 1.78 & 4.51 & 4.34 & 79.37 & 82.16 & 85.06 & 65.06 & 78.47 & 81.49 & 10.17 \\
\hline $\mathbf{T}_{6}$ & 1.45 & 3.37 & 4.10 & 83.61 & 87.51 & 87.06 & 71.87 & 83.90 & 82.62 & 5.44 \\
\hline $\mathbf{T}_{7}$ & 2.55 & 10.23 & 10.76 & 66.17 & 65.02 & 66.40 & 50.31 & 51.38 & 54.00 & 18.44 \\
\hline$T_{8}$ & 2.18 & 7.91 & 8.75 & 68.20 & 67.90 & 69.68 & 57.66 & 62.29 & 62.53 & 16.78 \\
\hline$T_{9}$ & 1.00 & 2.89 & 3.40 & 87.18 & 90.91 & 89.54 & 80.66 & 86.21 & 85.25 & 2.13 \\
\hline$T_{10}$ & 1.25 & 3.20 & 3.97 & 86.31 & 87.63 & 88.29 & 75.69 & 84.67 & 82.47 & 5.20 \\
\hline $\mathbf{T}_{11}$ & 2.72 & 10.85 & 12.41 & 62.22 & 55.58 & 56.91 & 47.08 & 48.46 & 45.85 & 20.09 \\
\hline$T_{12}$ & 3.10 & 12.86 & 14.77 & 49.89 & 46.56 & 43.81 & 39.48 & 38.94 & 35.73 & 26.95 \\
\hline S.Em \pm & 0.13 & 0.45 & 0.96 & 2.60 & 2.82 & 3.43 & 2.11 & 1.86 & 3.70 & 1.34 \\
\hline C.D. $(0.05)$ & 0.37 & 1.32 & 2.82 & 7.63 & 8.28 & 10.05 & 6.18 & 5.46 & 10.86 & 3.92 \\
\hline
\end{tabular}


Table.2 Effect of weed management practices on number of tillers, plant dry matter accumulation, crop growth rate and relative growth rate

\begin{tabular}{|c|c|c|c|c|c|c|c|c|c|c|}
\hline \multirow[t]{2}{*}{ Treatment } & \multicolumn{3}{|c|}{ Number of tillers $\left(\mathrm{m}^{-2}\right)$} & \multicolumn{3}{|c|}{$\begin{array}{l}\text { Dry matter accumulation of } \\
\text { plant }\left(\mathrm{g} \mathrm{m}^{-2}\right)\end{array}$} & \multicolumn{2}{|c|}{$\begin{array}{l}\text { Crop growth rate } \\
\qquad\left(\mathrm{g} \mathrm{m}^{-2} \mathrm{~d}^{-1}\right)\end{array}$} & \multicolumn{2}{|c|}{$\begin{array}{l}\text { Relative growth rate } \\
\qquad\left(g^{-1} \mathbf{d}^{-1}\right)\end{array}$} \\
\hline & 30DAT & 45DAT & 60DAT & 30DAT & 45DAT & 60DAT & 30-60DAT & 60-90DAT & 30-60DAT & 60-90DAT \\
\hline $\mathbf{T}_{1}$ & 183.35 & 210.00 & 190.00 & 1287.00 & 1872.00 & 2860.00 & 19.50 & 32.92 & 0.012 & 0.014 \\
\hline $\mathbf{T}_{2}$ & 260.66 & 297.00 & 264.50 & 1624.00 & 2346.00 & 3324.00 & 24.07 & 32.61 & 0.012 & 0.012 \\
\hline $\mathbf{T}_{\mathbf{3}}$ & 199.15 & 240.00 & 212.50 & 1345.00 & 2011.00 & 2930.00 & 22.19 & 30.64 & 0.013 & 0.013 \\
\hline $\mathbf{T}_{4}$ & 192.50 & 235.00 & 210.00 & 1310.00 & 1895.00 & 2885.00 & 19.50 & 33.00 & 0.012 & 0.014 \\
\hline $\mathbf{T}_{5}$ & 210.85 & 250.00 & 220.00 & 1401.00 & 2126.00 & 2990.00 & 24.15 & 28.81 & 0.014 & 0.011 \\
\hline $\mathbf{T}_{6}$ & 229.38 & 267.66 & 235.00 & 1467.00 & 2147.00 & 3106.00 & 22.67 & 31.98 & 0.013 & 0.012 \\
\hline $\mathbf{T}_{7}$ & 200.00 & 242.50 & 215.00 & 1360.00 & 2090.00 & 2965.00 & 24.34 & 29.16 & 0.014 & 0.012 \\
\hline $\mathbf{T}_{8}$ & 210.85 & 252.50 & 217.50 & 1370.00 & 2102.00 & 2975.00 & 24.42 & 29.08 & 0.014 & 0.012 \\
\hline $\mathbf{T}_{9}$ & 255.96 & 297.00 & 258.83 & 1568.00 & 2286.00 & 3225.00 & 23.95 & 31.30 & 0.013 & 0.011 \\
\hline $\mathbf{T}_{10}$ & 230.24 & 273.00 & 237.66 & 1525.00 & 2156.00 & 3167.00 & 21.01 & 33.70 & 0.012 & 0.013 \\
\hline $\mathbf{T}_{11}$ & 199.20 & 242.50 & 212.50 & 1347.00 & 2043.00 & 2942.00 & 23.17 & 30.00 & 0.014 & 0.012 \\
\hline $\mathbf{T}_{12}$ & 195.85 & 237.50 & 212.50 & 1325.00 & 1955.00 & 2910.00 & 21.00 & 31.83 & 0.013 & 0.013 \\
\hline S.Em \pm & 3.97 & 6.11 & 4.69 & 13.64 & 21.27 & 19.54 & 0.80 & 0.99 & 0.0004 & 0.0004 \\
\hline C.D. (0.05) & 11.66 & 17.91 & 13.77 & 40.02 & 62.38 & 57.31 & 2.35 & 2.91 & 0.0013 & 0.0012 \\
\hline
\end{tabular}


Table.3 Effects of weed management practices on yield attributes and yield of transplanted rice

\begin{tabular}{|c|c|c|c|c|c|c|c|}
\hline \multirow[t]{2}{*}{ Treatment } & \multirow{2}{*}{$\begin{array}{c}\text { No. of Panicles } \\
\left(\mathrm{m}^{-2}\right)\end{array}$} & \multirow{2}{*}{$\begin{array}{l}\text { Filled grains } \\
\text { panicle }^{-1}\end{array}$} & \multirow{2}{*}{$\begin{array}{c}\text { Test weight } \\
\text { (g) }\end{array}$} & \multicolumn{3}{|c|}{ Yield $\left(\mathrm{t} \mathrm{ha} \mathbf{a}^{-1}\right)$} & \multirow{2}{*}{$\begin{array}{c}\text { Harvest index } \\
(\%)\end{array}$} \\
\hline & & & & Grain & Straw & Total & \\
\hline $\mathbf{T}_{1}$ & 168.33 & 100.66 & 18.00 & 2.02 & 4.38 & 6.40 & 31.56 \\
\hline $\mathbf{T}_{2}$ & 240.16 & 142.36 & 18.11 & 4.23 & 6.36 & 10.59 & 39.94 \\
\hline $\mathbf{T}_{3}$ & 192.50 & 123.33 & 18.17 & 3.13 & 5.17 & 8.30 & 37.71 \\
\hline $\mathbf{T}_{4}$ & 185.83 & 120.00 & 18.09 & 3.05 & 5.08 & 8.13 & 37.52 \\
\hline $\mathbf{T}_{\mathbf{5}}$ & 208.66 & 130.33 & 18.21 & 3.80 & 5.88 & 9.68 & 39.26 \\
\hline$T_{6}$ & 221.33 & 133.00 & 18.20 & 4.00 & 6.15 & 10.15 & 39.41 \\
\hline $\mathbf{T}_{7}$ & 196.66 & 127.66 & 18.16 & 3.45 & 5.47 & 8.92 & 38.68 \\
\hline $\mathbf{T}_{8}$ & 198.33 & 129.33 & 18.13 & 3.52 & 5.50 & 9.02 & 39.02 \\
\hline $\mathbf{T}_{9}$ & 239.00 & 140.66 & 18.21 & 4.14 & 6.34 & 10.48 & 39.50 \\
\hline $\mathbf{T}_{10}$ & 230.18 & 136.33 & 18.00 & 4.01 & 6.21 & 10.22 & 39.24 \\
\hline $\mathbf{T}_{11}$ & 193.16 & 124.33 & 18.10 & 3.38 & 5.39 & 8.77 & 38.54 \\
\hline $\mathbf{T}_{12}$ & 190.33 & 121.00 & 18.09 & 3.09 & 5.12 & 8.21 & 37.64 \\
\hline S.Em \pm & 1.61 & 1.14 & 0.04 & 0.07 & 0.10 & 0.16 & - \\
\hline C.D. (0.05) & 4.73 & 3.34 & 0.11 & 0.21 & 0.29 & 0.48 & - \\
\hline
\end{tabular}


Table.4 Economics of transplanted kharif rice as influenced by weed management practices

\begin{tabular}{|c|c|c|c|c|c|c|}
\hline Treatment & $\begin{array}{l}\text { Common cost } \\
\left(\operatorname{Rs~ha}^{1}\right)\end{array}$ & $\begin{array}{l}\text { Treatment cost } \\
\left(\mathrm{Rs} \mathrm{ha}^{1}\right)\end{array}$ & $\begin{array}{l}\text { Total cost } \\
\left(\mathbf{R s} \mathbf{h a}^{1}\right)\end{array}$ & $\begin{array}{c}\text { Gross return } \\
\left(\operatorname{Rs~ha}^{1}\right)\end{array}$ & $\begin{array}{l}\text { Net return } \\
\left(\text { Rs ha }^{1}\right)\end{array}$ & Input: Output \\
\hline $\mathbf{T}_{1}$ & 33460.00 & 00 & 33460.00 & 34074.00 & 614.00 & $1: 1.02$ \\
\hline$\overline{T_{2}}$ & 33460.00 & 12000.00 & 45460.00 & 68541.00 & 23081.00 & $1: 1.51$ \\
\hline$\overline{T_{3}}$ & 33460.00 & 6000.00 & 39460.00 & 51181.00 & 11721.00 & $1: 1.30$ \\
\hline $\mathbf{T}_{4}$ & 33460.00 & 1000.00 & 34460.00 & 49915.00 & 15455.00 & $1: 1.45$ \\
\hline $\mathbf{T}_{5}$ & 33460.00 & 1845.00 & 35305.00 & 61740.00 & 26435.00 & $1: 1.75$ \\
\hline$T_{6}$ & 33460.00 & 2642.50 & 36102.50 & 64950.00 & 28847.50 & $1: 1.80$ \\
\hline$\overline{T_{7}}$ & 33460.00 & 4670.00 & 38130.00 & 56185.00 & 18055.00 & $1: 1.47$ \\
\hline $\mathbf{T}_{8}$ & 33460.00 & 3100.00 & 36560.00 & 57244.00 & 20684.00 & $1: 1.57$ \\
\hline $\mathbf{T}_{9}$ & 33460.00 & 4515.00 & 37975.00 & 67198.00 & 29223.00 & $1: 1.77$ \\
\hline $\mathrm{T}_{10}$ & 33460.00 & 3845.00 & 37305.00 & 65157.00 & 27852.00 & $1: 1.75$ \\
\hline$\overline{T_{11}}$ & 33460.00 & 2430.00 & 35890.00 & 55076.00 & 19186.00 & $1: 1.53$ \\
\hline $\mathrm{T}_{12}$ & 33460.00 & 1670.00 & 35130.00 & 50543.00 & 15413.00 & $1: 1.44$ \\
\hline
\end{tabular}




\section{Yield attributes and yield of rice}

The data pertaining to yield components i.e. number of panicles $\mathrm{m}^{-2}$, number of filled grains panicle ${ }^{-1}$, test weight (1000 grain weight in g) showed that every parameter was influenced by different weed management practices.

The highest number of panicles per $\mathrm{m}^{-2}$ (240.16) was recorded with the weed free treatment $\left(\mathrm{T}_{2}\right)$ being statistically at par with $\mathrm{T}_{9}$ i.e. pretilachlor $0.60 \mathrm{~kg}$ a.i $\mathrm{ha}^{-1}+$ bispyribac sodium 10\% SC @ $20 \mathrm{~g}_{\text {a.i ha }}{ }^{-1}$ at 22-25 DAT + paddy weeder at 40 DAT (239.00).

The lowest number of panicles $\mathrm{m}^{-2}(168.33)$ was recorded with weedy check. The highest number of filled grains panicle ${ }^{-1}$ (142.36) was recorded with weed free $\left(T_{2}\right)$ treatment being at par with $\mathrm{T}_{9}$ i.e. pretilachlor $0.60 \mathrm{~kg}$ a.i ha ${ }^{-1}$ + bispyribac sodium 10\% SC @ $20 \mathrm{~g}$ a.i ha ${ }^{-1}$ at 22-25 DAT + paddy weeder at 40 DAT (140.66). The lowest number of grains panicle $^{-1}(100.66)$ was recorded with the weedy check $\left(\mathrm{T}_{1}\right)$.

Test weight (g per 1000 grains) was very minutely influenced by the weed management practices. All treatments exhibited test weight around $18.10 \mathrm{~g}$ (Table 3).

The highest grain yield of rice $\left(4.23 \mathrm{tha}^{-1}\right)$ and straw yield of rice $\left(6.36 \mathrm{t} \mathrm{ha}^{-1}\right)$ was obtained with weed free $\left(T_{2}\right)$. Among the treatments excepting weed free $\left(\mathrm{T}_{2}\right)$, highest grain yield $\left(4.14 \mathrm{t} \mathrm{ha}^{-1}\right)$ and highest straw yield $\left(6.34 \mathrm{t} \mathrm{ha}^{-1}\right)$ was recorded from $\mathrm{T}_{9}$ being statistically at par with bispyribac sodium 10\% SC @ $20 \mathrm{~g}$ a.i ha ${ }^{-1}$ at 20 DAT + paddy weeder at 40 DAT i.e. $\mathrm{T}_{10}$ and bispyribac sodium 10\% SC @ 30 g a.i ha ${ }^{-1}$ at 14 DAT i.e. $\mathrm{T}_{6}$. The lowest grain yield $\left(2.02 \mathrm{t} \mathrm{ha}^{-1}\right)$ and straw yield $\left(4.38 \mathrm{t} \mathrm{ha}^{-1}\right)$ was obtained from $\mathrm{T}_{1}$ i.e. weedy check (Table 3 and Figure 8).

\section{Economics of rice}

\section{Gross return (Rs ha $\left.{ }^{-1}\right)$}

In case of different weed management practices in transplanted paddy, highest gross return (Rs. 68541.00/ha) was obtained from $\mathrm{T}_{2}$ i.e. weed free followed by $\mathrm{T}_{9}$ (Rs. 67198.00/ha) i.e. Pretilachlor $0.60 \mathrm{~kg}$ a.i. $\mathrm{ha}^{-1}$ + Bispyribac sodium 10\% SC @ 20 g a.i. ha ${ }^{-1}$ at 22-25 DAT + Paddy weeder at 40 DAT. Lowest gross return was obtained from control treatment i.e. weedy check (Rs. 34074.00/ha).

\section{Net return $\left(\right.$ Rs ha $\left.^{-1}\right)$}

It was clear from the data presented in Table 4 and Figure 9 that in case of different weed management practices in transplanted paddy, highest net return was obtained from $\mathrm{T}_{9}$ (Rs. 29223.00/ha) i.e. Pretilachlor $0.60 \mathrm{~kg}$ a.i. $\mathrm{ha}^{-1}$ + Bispyribac sodium 10\% SC @ $20 \mathrm{~g}$ a.i. $\mathrm{ha}^{-1}$ at 22-25 DAT + Paddy weeder at 40 DAT followed by $\mathrm{T}_{6}$ i.e. Bispyribac sodium $10 \%$ SC @ $30 \mathrm{~g}$ a.i. ha ${ }^{-1}$ at 14 DAT (Rs. 28847.00/ha). Lowest net return was obtained from control treatment i.e. weedy check (Rs. 614.00/ha).

\section{Input: Output}

It was evident from the data presented in Table 4 and Figure 10 that in case of different weed management practices in transplanted paddy, highest input: output was obtained $\mathrm{T}_{6}$ i.e. Bispyribac sodium 10\% SC @ $30 \mathrm{~g}$ a.i. $\mathrm{ha}^{-1}$ at 14 DAT (1:1.80) narrowly followed by $\mathrm{T}_{9}(1: 1.77)$ i.e. Pretilachlor $0.60 \mathrm{~kg}$ a.i. $\mathrm{ha}^{-1}+$ Bispyribac sodium 10\% SC @ $20 \mathrm{~g}$ a.i. ha ${ }^{-1}$ at 22-25 DAT + Paddy weeder at 40 DAT. This was due to the high cost of cultivation incurred in the treatment $\mathrm{T}_{9}$ as compared to in $\mathrm{T}_{6}$. Despite giving highest gross return, $\mathrm{T}_{2}$ also lagged behind in input: output due to its high cost of cultivation. Almost similar 
performance in terms of input: output was also exhibited by $\mathrm{T}_{5}$ and $\mathrm{T}_{10}(1: 1.75)$.

Lowest input: output was obtained from control treatment i.e. weedy check $(1: 1.02)$.

Highest input: output was obtained $\mathrm{T}_{6}$ i.e. Bispyribac sodium 10\% SC @ $30 \mathrm{~g}$ a.i. ha ${ }^{-1}$ at 14 DAT (1:1.80) narrowly followed by $\mathrm{T}_{9}$ $(1: 1.77)$ i.e. Pretilachlor $0.60 \mathrm{~kg}$ a.i. $\mathrm{ha}^{-1}+$ Bispyribac sodium 10\% SC @ 20 g a.i. ha ${ }^{-1}$ at 22-25 DAT + Paddy weeder at 40 DAT. This was due to the high cost of cultivation incurred in the treatment $T_{9}$ as compared to in $\mathrm{T}_{6}$. So, it can be concluded that $\mathrm{T}_{6}$ i.e. Bispyribac sodium 10\% SC @ 30 g a.i. ha ${ }^{-1}$ at 14 DAT or T9 i.e. Pretilachlor $0.60 \mathrm{~kg}$ a.i. ha ${ }^{-1}$ + Bispyribac sodium 10\% SC @ 20 g a.i. ha ${ }^{-1}$ at 22-25 DAT + Paddy weeder at 40 DAT can be opted to reduce the weed population and to reduce the crop weed competition and for increasing economic return of paddy.

\section{References}

Anonymous. (2011). Vision 2013. Central Rice Research Institute, ICAR, Cuttack, Odisha. Pp. 1, 9.

Chatterjee, B. N. and Maiti, S. (1981). Principles and practices of Rice Growing, $2^{\text {nd }}$ edn. Oxford and IBH Publications, New Delhi. Pp. 293.

DDR. (1990). Annual Report, 1988-89, Directorate of Rice Research Hyderabad, India. Pp. 37.
Fisher, S. R. A. and Yates, F. (1963). Statistical table for biology, agricultural and medical research, Oliver and Boyd. Edinburgh Tweedale Court, London (6th Edn.).

Gomez, K. A. and Gomez, A. A. (1984). Statistical Procedure for Agricultural Research. John Willy and Sons, New York. Pp. 316.

Manhas, S.S., G. Singh, D. Singh and V. Khajuria, (2012). Effect of tank-mixed herbicides on weeds and transplanted rice (Oryza sativa L.). Annual Agriculture Research, New Ser., 33: 2531.

NRCWS, (2007). National Research Centre for Weed Science Perspective Plan Vision 2025. National Research Centre for Weed Science, Jabalpur, Madhya Pradesh.

Rao, V. S. (1983). Principles of weed science, Oxford and IBH publishing comp., New Delhi. pp. 23-42.

Singh, P., P. Singh, R. Singh and K.N. Singh, (2007). Efficacy of new herbicides in transplanted rice (Oryza sativa) under temperate conditions of Kashmir. Indian Journal of Weed Science, 39: 167-171.

Varshney, J. G. and Prasad Babu, M. B. B. (2008). Future scenario of weed management in India. Indian Journal of Weed Science, 40 (1\&2): 1-9.

\section{How to cite this article:}

Jaladhar Gorain, Koushik Patra and Parthendu Poddar. 2018. Growth, Yield and Economics of Transplanted Rice (Oryza sativa L.) as Influenced by Different Weed Management Practices. Int.J.Curr.Microbiol.App.Sci. 7(06): 348-362. doi: https://doi.org/10.20546/ijcmas.2018.706.039 